\title{
EVALUASI MEKANISME PEMOTONGAN DAN PELAPORAN PAJAK OLEH BENDAHARAWAN PEMERINTAH PADA BADAN PERENCANAAN PENELITIAN DAN PEMBANGUNAN KABUPATEN MINAHASA SELATAN
}

\author{
Arnestha Tumbel ${ }^{1}$, Herman Karamoy ${ }^{2}$, Victorina Tirayoh ${ }^{3}$ \\ ${ }^{1,2,3}$ Fakultas Ekonomi dan Bisnis. Jurusan Akuntansi. Universitas Sam Ratulangi, J1. Kampus Bahu, Manado, \\ 95115, Indonesia \\ E-mail :arnesthatumbel@gmail.com
}

\begin{abstract}
Taxes are the main source of state revenue used to finance development and development. In accordance with the provisions applicable in the taxation field, the party who deducts / taxes the goods derived from the State Revenue and Expenditure Budget $(A P B N)$ is the government treasurer. Income tax liability. VAT) and. Tax collection (VAT), among others, is the withholding or collection of income tax article 21, Article 22, Article 23,. The purpose of this study is to find out how the mechanism of cutting and reporting by the National Agency for Research and Development of South Minahasa District. The method used is descriptive analysis. The results of this study indicate Research and Development Planning Agency South Minahasa regency has been carrying out obligations in cutting and article 21, article 22, PPn. However, reporting is delayed from the deadline. We recommend that the Research and Development Planning Agency of South Minahasa Regency always pay attention to the time of reporting to not exceed the time limit specified in order to avoid. Keywords: Deductions \& reporting, Income tax, Value added, Government treasurer
\end{abstract}

\section{PENDAHULUAN}

Seiring dengan perkembangan perekonomian Indonesia akan diikuti pula dengan kebijakan-kebijakan di bidang pajak. Pajak telah diaanggap sebagai salah satu kewajiban warga negara untuk ikut berpartisipasi dalam membantu pelaksanaan tugas pemerintah. Pajak merupakan pungutan yang dilakukan pemerintah berdasarkan undang-undang yang ada tanpa harus memberikan imbalan langsung. Pajak merupakan sumber penerimaan utama Negara yang digunakan untuk membiayai pengeluaran pemerintah dan pembangunan. Hal ini tertuang dalam Anggaran Penerimaan dan Belanja Negara (APBN) dimana penerimaan pajak merupakan penerimaan dalam negeri yang terbesar. Semakin besarnya pengeluaran pemerintah dalam rangka pembiayaan negara menuntut peningkatan penerimaan negara yang salah satunya berasal dari penerimaan pajak.

Sesuai dengan ketentuan yang berlaku di bidang perpajakan, pihak yang melakukan pemotongan/pemungutan pajak atas pengeluaran yang berasal dari Anggaran Pendapatan dan Belanja Negara (APBN) atau Anggaran Pendapatan dan Belanja Daerah (APBD) adalah bendaharawan pemerintah. Termasuk dalam pengertian bendaharawan pemerintah adalah pemegang kas dan pejabat lain yang menjalankan fungsi yang sama. Sebagai pihak yang melakukan pemotongan/pemungutan pajak, bendaharawan harus mengetahui aspek-aspek perpajakan terutama yang berkaitan dengan kewajiban untuk melakukan pemotongan atau pemungutan pajak Penghasilan serta Pajak Pertambahan Nilai.

Transparansi dalam sistem pemerintahan semakin meningkat, tidak terkecuali transparansi perpajakan. Bendahara yang telah mendaftarkan diri sebagai Wajib Pajak wajib memenuhi kewajiban sebagaimana ditentukan dalam peraturan perundang-undangan. Bahkan disetiap tahunnya Direktorat Jenderal Pajak selalu menerbitkan edaran mengenai pengawasan mutlak atas pelaksanaan pengawasan pembayaran Bendahara Pemerintah. Dengan 
diterbitkannya pengumuman Kementrian Keuangan Republik Indonesia Nomor. PENG-05 PJ.09/2010 (www.depkeu.go.id) menjelaskan bahwa bendahara mempunyai kewajiban untuk melakukan pemungutan/pemotongan, penyetoran, dan pelaporan pajak ke Kantor Pelayanan Pajak sesuai batas waktu yang ditentukan.

Dalam melaksanakan kewajiban tersebut, masyarakat juga bisa ikut serta dalam mengawasi bagaimana pelaksanaan pemotongan atau pemungutan pajak yang dilakukan oleh bendahara pemerintah. Apabila bendahara lalai dalam menjalankan tugasnya, maka akan mengakibatkan berkurangnya penerimaan pajak sehingga akan menurunkan kemampuan Pemerintah untuk mengatasi pengangguran, kemiskinan, dan rencana pembangunan di Indonesia. Agar tidak menimbulkan kesalahan dalam pemotongan hingga pelaporan Pajak maka pemahaman dari bendaharawan pemerintah dan pihak lain yang terkait dengan pemotongan dan pelaporan Pajak Penghasilan Pasal 21, Pajak Penghasilan Pasal 22, Pajak Penghasilan Pasal 23, Pajak Penghasilan Pasal 4 ayat (2) dan Pajak Pertambahan Nilai tersebut harus sesuai dengan ketentuan perpajakan yang berlaku. Adapun tujuan yang ingin dicapai dalam penelitian ini adalah :

1. Untuk mengetahui bagaimana proses pemotongan pajak oleh bendaharawan pemerintah di Badan Perencanaan Penelitian dan Pembangunan Kabupaten Minahasa Selatan.

2. Untuk mengetahui bagaimana proses pelaporan pajak oleh bendahara pemerintah Badan Perencanaan Penelitian dan Pembangunan Kabupaten Minahasa Selatan.

\section{TINJAUAN PUSTAKA}

\subsection{Konsep Akuntansi Pajak}

Secara sederhana Akuntansi Perpajakan dapat didefinisikan sebagai bidang akuntansi yang mengkalkulasi, menangani, mencatat, bahkan menganalisa dan membuat strategi perpajakan sehubungan dengan kejadian-kejadian ekonomi (transaksi) oleh perusahaan, organisasi maupun di pemerintahan.

\subsection{Konsep Perpajakan \\ Definisi Pajak}

Definisi pajak menurut Undang-Undang (UU) Pajak Nomor 28 tahun 2007 menyatakan pajak adalah kontribusi wajib kepada negara yang bersifat memaksa berdasarkan UU dengan tidak mendapatkan imbalan secara langsung dan digunakan untuk keperluan negara demi kemakmuran dan kesejahteraan rakyat.

\section{Fungsi Pajak}

Menurut Mardiasmo (2016:1) pajak mempunyai beberapa fungsi, yaitu:

1. Fungsi Anggaran (Budgeter)

2. Fungsi Mengatur (Regulerend)

\subsection{Pajak Penghasilan}

Menurut Tmbooks (2013) Pajak Penghasilan (PPh) merupakan jenis pajak subjektif yang kewajiban pajaknya melekat pada subjek pajak yang bersangkutan, artinya kewajiban pajak tersebut dimaksudkan untuk tidak dilimpahkan kepada subjek pajak lainnya.

\section{Pajak Penghasilan Pasal 21}

Dalam buku Mardiasmo (2016) Pajak Penghasilan Pasal 21 adalah pajak atas penghasilan berupa gaji, upah, honorarium, tunjangan, dan pembayaran lain dengan nama dan dalam bentuk apapun sehubungan dengan pekerjaan atau jabatan, jasa, dan kegiatan yang dilakukan oleh orang pribadi Subjek Pajak dalam negeri, sebagaimana dimaksud dalam Pasal 21 Undang-Undang Pajak Penghasilan. 


\section{Pemotongan Pajak Penghasilan Pasal 21}

Dalam buku Mardiasmo (2016) pemotongan PPh Pasal 21 meliputi:

Pemberi kerja yang terdiri dari:

1) Orang pribadi;

2) Badan; atau

3) Cabang perwakilan, atau unit, dalam hal yang melakukan sebagian atau seluruh administrasi yang terkait dengan pembayaran gaji, upah, honorarium, tumjangan, dan pembayaran lain adalah cabang, perwakilan, atau unit tersebut;

1) Bendaharawan atau pemegang kas pemerintah, termasuk bendahara atau pemegang kas pada Pemerintah Pusat termasuk institusi TNI/POLRI, Pemerintah Daerah, instansi atau lembaga pemerintah.

2) Dana pensiun, badan penyelenggara jaminan sosial tenaga kerja, dan badanbadan lain yang membayar uang pensiun secara berkala dan tunjangan hari tua atau jaminan hari tua;

3) Orang pribadi yang melakukan kegiatan usaha atau pekerjaan bebas serta badan.

4) Penyelenggara kegiatan, termasuk badan pemerintah, organisasi yang bersifat nasional dan internasional,perkumpulan, orang pribadi serta lembaga lainnya yang menyelenggarakan kegiatan, yang membayar honorarium, hadiah, atau penghargaan dalam bentuk apapun kepada Wajib Pajak orang pribadi berkenaan dengan suatu kegiatan.

\section{Tarif Pemotongan PPh Pasal 21}

Undang-Undang Nomor 36 Tahun 2008 Tentang Pajak Penghasilan, tarif pemotongan pajak yaitu:

1) Sampai dengan Rp50.000.000,00 (lima puluh juta rupiah) 5\% (lima persen).

2) Di atas Rp50.000.000,00 (lima puluh juta rupiah) sampai dengan Rp250.000.000,00 (dua ratus lima puluh juta rupiah) $15 \%$ (lima belas persen) .

3) $\mathrm{Di}$ atas $\mathrm{Rp} 250.000 .000,00$ (dua ratus lima puluh juta rupiah) sampai dengan Rp500.000.000,00 (lima ratus juta rupiah) $25 \%$ (dua puluh lima persen) .

4) Di atas Rp500.000.000,00 (lima ratus juta rupiah) 30\% (tiga puluh persen).

\section{Pajak Penghasilan Pasal 22}

Dalam buku Mardiasmo (2016) Pajak Penghasilan 22 merupakan pembayaran pajak penghasilan dalam tahun berjalan yang dipungut oleh:

1) Bendahara pemerintah, termasuk bendahara pada Pemerintah Pusat, Pemerintah Daerah, instansi atau lembaga pemerintah, dan lembaga-lembaga negara lainya, berkenaan dengan pembayaran atas penyerahan barang, termasuk juga dalam pengertian bendahara adalah pemegang kasdan pejabat lain yang menjalankan fungsi yang sama.

2) Badan-badan tertentu, baik badan pemerintah maupun swasta, berkenaan dengan kegiatan di bidang impor atau kegiatan usaha di bidang lain, seperti kegiatan usaha produksi barang tertentu antara lain otomotif dan semen; dan

3) Wajib Pajak badan tertentu untuk memungut pajak dari pembeli atas penjualan barang yang tergolong sangat mewah. Pemungutan pajak oleh Wajib Pajak badan tertentu ini akan dikenakan terhadap pembelian barang yang memenuhi kriteria tertentu sebagai barang yang tergolong sangat mewah baik dilihat dari jenis barangnya maupun harganya, seperti kapal pesiar, rumah sangat mewah, apartemen dan kondominium sangat mewah, serta kendaraan sangat mewah.

\section{Objek dan Tarif PPh Pasal 22}

Dalam buku Mardiasmo (2016) berkenaan dengan pembayaran atas pembelian barang yang dilakukan oleh: 
(a) Bendahara Pemerintah dan Kuasa Pengguna Anggaran (KPA) sebagai pemungut pajak pada Pemerintah Pusat, Pemerintah Daerah, instansi atau lembaga pemerintah dan lembagalembaga negara lainnya;

(b) Bendahara pengeluaran dengan mekanisme uang persediaan (UP)

(c) KPA atau pejabat penerbiit Surat Perintah Membayar yang diberi delegasi oleh KPA, kepada pihak ketiga yang dilakukan dengan mekanisme pembayaran langsung;

Dikenakan PPh pasal 22 sebesar 1,5\% dari harga pembelian tidak termasuk Pajak Pertambahan Nilai.

\section{Pajak Penghasilan Pasal 23}

Dalam buku Mardiasmo (2016) ketentuan dalam pasal 23 UU PPh mengatur pemotongan pajak atas penghasilan yang diterima atau diperoleh Wajib Pajak dalam Negeri dan Bentuk Usaha Tetap yang berasal dari modal, penyerahan jasa, atau penyelenggaraan kegiatan selain yang telah dipotong Pajak Penghasilan Pasal 21, yang dibayarkan, disediakan untuk dibayarkan, atau telah jatuh tempo pembayaranya oleh badan pemerintah, subjek pajak badan dalam negeri, penyelenggara kegiatan, bentuk usaha tetap, atau perwakilan perusahaan luar negeri lainnya.

Besarnya tarif pemotongan PPh Pasal 23 adalah:

1) Sebesar $15 \%$ dari jumlah bruto atas :

(a) Dividen

(b) Bunga termasuk premium, diskonto, dan imbalan karena jaminan pengembalian utang

(c) Royalti

(d) Hadiah, penghargaan, bonus, dan sejenisnya selain yang telah dipotong Pajak Penghasilan pasal 21.

2) Sebesar $2 \%$ dari jumlah bruto yang tidak termasuk Pajak Pertambahan Nilai atas :

(a) Sewa dan penghasilan lain sehubungan dengan penggunaan harta, kecuali sewa tanah dan/atau bangunan.

(b) Imbalan sehubungan dengan jasa teknik, jasa manajemen, jasa konstruksi, jasa konsultan, dan jasa lain selain jasa yang telah dipotong Pajak Penghasilan Pasal 21.

\section{Pajak Penghasilan Pasal 4 ayat (2)}

Dalam buku Mardiasmo (2016) Pasal 4 ayat (2) Undang-undang Pajak Penghasilan menyebutkan, bahwa: Atas penghasilan berupa bunga deposito, dan tabungan-tabungan lainnya, penghasilan dari transaksi saham dan sekuritas laiinya di bursa efek, peghasilan dari pengalihan harta berupa tanah dan/bangunan serta penghasilan tertentu lainnya, pengenaan pajaknya diatur dengan Peraturan Pemerintah.

\section{Pajak Pertambahan Nilai}

Mardiasmo (2016) apabila dilihat dari sejarahnya, Pajak Pertambahan Nilai merupakan pengganti dari Pajak Penjualan. Alasan penggantian ini karena Pajak Penjualan dirasa sudah tidak lagi memadai untuk menampung kegiatan masyarakat dan belim mencapai sasaran kebutuhan pembangunan, antara lain untuk meningkatkan penerimaan negara, mendorong ekspor, dan pemerataan pembebanan pajak.

Berdasarkan Undang-Undang Nomor 8 Tahun 2009 tentang Perubahan Ketiga Atas UndangUndang Nomor 8 tahun 1983 tentang Pajak Pertambahan Nilai barang dan jasa dan Pajak penjualan atas barang mewah, tarif Pajak Pertambahan Nilai adalah sebesar $10 \%$ atas pembelian Barang Kena Pajak.

\section{Objek Pajak Pertambahan Nilai}

PPN dikenakan atas

1) Penyerahan BKP di dalam Daerah Pabean yang dilakukan oleh Pengusaha. Syaratsyaratnya adalah :

(a) Barang berwujud yang diserahkan merupakan BKP. 
(b) Barang tidak berwujud yang diserahkan merupakan BKP tidak berwujud.

(c) Penyerahan dilakukan di dalam Daerah Pabean

(d) Penyerahan dilakukan dalam rangka kegiatan usaha atau pekerjaannya.

2) Impor BKP

3) Penyerahan JKP di dalam Daerah Pabean yang dilakukan oleh Pengusaha. Syaratsyaratnya adalah :

(a) Jasa yang diserahkan merupakan JKP

(b) Penyerahan dilakukan di dalam Daerah Pabean

(c) Penyerahan dilakukan dalam rangka kegiatan usaha atau pekerjaannya.

4) Pemanfaatan BKP tidak berwujud dari luar Daerah Pabean di dalam Daerah Pabean.

5) Pemanfaatan JKP dari luar Daerah Pabean di dalam Daerah Pabean.

6) Ekspor BKP berwujud oleh Pengusaha Kena Pajak

7) Ekspor BKP tidak berwjud oleh Pengusaha Kena Pajak

8) Kegiatan membangun sendiri yang dilakukan tidak dalam kegiatan usaha atau pekerjaan oleh orang pribadi atau badan yang hasilnya digunakan sendiri atau digunakan pihak lain.

9) Penyerahan BKP berupa aktiva yang menurut tujuan semula tidak untuk diperjualbelikan oleh PKP, kecuali atas penyerahan aktiva yang Pajak Masukannya tidak dapat dikreditkan (Mardiasmo, 2016).

\section{Pelaporan Pajak}

Menurut Mardiasmo (2016) Surat Pemberitahuan (SPT) adalah surat yang oleh Wajib Pajak digunakan untuk melaporkan penghitungan dan/atau pembayaran pajak, objek pajak dan/atau bukan objek pajak, dan/atau harta dan kewajiban sesuai dengan ketentuan peraturan perundang-undangan perpajakan.

Batas waktu pembayaran dan Pelaporan untuk kewajiban perpajakan bulanan

\begin{tabular}{|c|c|c|c|}
\hline No & Jenis SPT & Batas Waktu Pembayaran Masa & Batas WaktuPelaporan \\
\hline 1 & PPh Pasal 4 ayat (2) & Tgl. 10 bulan berikut & Tgl. 20 bulan berikut \\
\hline 2 & PPh Pasal 15 & Tgl. 10 bulan berikut & Tgl. 20 bulan berikut \\
\hline 3 & PPh Pasal 21/26 & Tgl. 10 bulan berikut & Tgl. 20 bulan berikut \\
\hline 4 & $\mathrm{PPh}$ Pasal 23/26 & Tgl. 10 bulan berikut & Tgl. 20 bulan berikut \\
\hline 5 & $\begin{array}{l}\text { PPh Pasal } 25 \text { (angsuran Pajak) untuk Wajib Pajak } \\
\text { orang pribadi dan badan }\end{array}$ & Tgl. 15 bulan berikut & Tgl. 20 bulan berikut \\
\hline 6 & $\begin{array}{l}\text { PPh Pasal } 25 \text { (angsuran Pajak) untuk Wajib Pajak } \\
\text { kriteria tertentu yang diperbolehkan melaporkan } \\
\text { beberapa Masa Pajak dalam satu SPT Masa }\end{array}$ & Akhir masa Pajak terakhir & $\begin{array}{l}\text { Tgl.20 setelah berakhirnya Masa } \\
\text { Pajak terakhir }\end{array}$ \\
\hline 7 & PPh Pasal 22, PPN \& PPn BM oleh Bea Cukai & 1 hari setelah dipungut & $\begin{array}{lrr}\begin{array}{l}\text { Hari kerja } \\
\text { berikutnya } \\
\text { mingguan) }\end{array} & \begin{array}{r}\text { terakhir } \\
\text { (melapor }\end{array} & \text { minggu } \\
\text { secara }\end{array}$ \\
\hline 8 & PPh Pasal 22 - Bendahara Pemerintah & Pada hari yang sama saat penyerahan barang & Tgl. 14 bulan berikut \\
\hline 9 & PPh Pasal 22 - Pertamina & Sebelum Delivery Order dibayar & \\
\hline 10 & PPh Pasal 22 - Pemungut tertentu & Tgl. 10 bulan berikut & Tgl. 20 bulan berikut \\
\hline 11 & PPN dan PPn BM - PKP & $\begin{array}{l}\text { Akhir bulan berikutnya setelah berakhirnya Masa Pajak } \\
\text { dan sebelum SPT Masa PPN disampaikan }\end{array}$ & $\begin{array}{l}\text { Akhir bulan berikutnya setelah } \\
\text { berakhirnya Masa Pajak }\end{array}$ \\
\hline 12 & PPN dan PPn BM - Bendaharawan & Tgl. 7 bulan berikut & Tgl. 14 bulan berikut \\
\hline 13 & PPN \& PPn BM - Pemungut Non Bendahara & Tgl. 15 bulan berikut & Tgl. 20 bulan berikut \\
\hline 14 & $\begin{array}{l}\text { PPh Pasal } 4 \text { ayat (2), Pasal 15,21,23, PPN dan } \\
\text { PPnBM Untuk Wajib Pajak Kriteria Tertentu }\end{array}$ & Sesuai batas waktu per SPT Masa & $\begin{array}{l}\text { Tgl.20 setelah berakhirnya Masa } \\
\text { Pajak terakhir }\end{array}$ \\
\hline
\end{tabular}

Batas waktu pembayaran danPelaporan untuk kewajiban perpajakan tahunan

\begin{tabular}{|c|l|l|l|}
\hline No & \multicolumn{1}{|c|}{ Jenis SPT } & \multicolumn{1}{|c|}{ Batas Waktu Pembayaran Tahunan } & \multicolumn{1}{c|}{ Batas WaktuPelaporan } \\
\hline 1 & PPh - Orang Pribadi & Sebelum SPT Tahunan PPh disampaikan & $\begin{array}{l}\text { akhir bulan ketiga setelah berakhirnya tahun atau bagian } \\
\text { tahun Pajak }\end{array}$ \\
\hline 2 & PPh - Badan & Sebelum SPT Tahunan PPh disampaikan & $\begin{array}{l}\text { akhir bulan keempat setelah berakhirnya tahun atau } \\
\text { bagian tahun Pajak }\end{array}$ \\
\hline 3 & PBB & 6 (enam) bulan sejak tanggal diterimanya SPPT & \\
\hline
\end{tabular}




\section{Bendaharawan Pemerintah}

Menurut Kamus Besar Bahasa Indonesia (Poerwadarminta, 2003), bendaharawan adalah setiap orang yang diberi tugas menerima, menyimpan, membayar dan/atau menyerahkan uang atau surat berharga atau barang-barang negara. Secara sederhana bendaharawan adalah mereka yang bekerja di BUMN atau pemerintah, baik pusat maupun daerah yang mengelola APBN/APBD dan yang ditunjuk oleh atasannya untuk menjabat menjadi pejabat bendaharawan pemerintah dengan surat keputusan pengangkatan. Berdasarkan keputusan Menteri Keuangan, bendaharawan pemerintah, yaitu bendaharawan dan pejabat yang melakukan pembayaran yang dananya berasal dari APBN/APBD, ditetapkan sebagai pemungut PPn dan PPh Pasal 22. Selain sebagai Pemungut, bedaharawan pemerintah juga sebagai pemotong $\mathrm{PPh}$ pasal 21, $\mathrm{PPh}$ pasal 22, $\mathrm{PPh}$ pasal 23, dan $\mathrm{PPh}$ pasal 4 ayat (2) sebagaiman ketentuan yang berlaku umum.

\subsection{Penelitian Terdahulu}

1. Kiki Ratnafuri/2012 dengan judul Malpraktek pemotongan dan pemungutan pajak oleh bendahara pemerintah. Tujuan penelitian ini adalah untuk mengidentifikasi malpraktek yang terjadi dalam pelaksanaan pemotongan dan pemungutan pajak oleh bendahara pemerintah serta menjelaskan penyebab terjadinya malpraktek dalam pelaksanaan. Metode penelitian menggunakan metode kualitatif pendekatan analisis deskriptif. Hasil penelitian menunjukkan pelaksanaan pemotongan dan pemungutan pajak oleh bendahara pemerintah masih belum optimal.

2. Clifvan Thomas Sorongan/ 2014 dengan judul Perhitungan Dan Pelaporan Pajak Penghasilan Pasal 22 Atas Pengadaan Barang Pada Kantor Pelayanan Perbendaharaan Negara Kota Bitung. Tujuan penelitian ini untuk mengetahui mekanisme perhitungan dan pelaporan Pajak Penghasilan Pasal 22 atas pengadaan barang pada Kantor Pelayanan Perbendaharaan Negara Kota Bitung. Metode Penelitian Menggunakan metode penelitian deskriptif. Hasil penelitian secara keseluruhan perhitungan sudah sesuai dengan peraturan perpajakan, namun dalam hal pelaporannya masih belum mengikuti peraturan perpajakan yang berlaku.

\section{PENELITIAN}

\subsection{Jenis Penelitian}

Dalam penelitian ini digunakan jenis penelitian deskripsif dengan pendekatan kualitatif dengan cara peneliti secara langsung berinteraksi dengan objek penelitian. Penelitian kualitatif dalam Sugiono (2016:1) adalah metode penelitian yang digunakan untuk meneliti pada kondisi objek yang alamiah, dimana peneliti adalah instrument kunci, teknik pengumpulan data dilakukan secara triangulasi (gabungan), analisis data bersifat induktif dan hasil penelitian kualitatif lebih menekankan makna dari pada generalisasi.

\subsubsection{Tempat dan Waktu Penelitian}

Lokasi penelitian di lakukan di Amurang tepatnya pada salah satu Instansi Pemerintahan yaitu Badan Perencanaan Penelitian dan Pegembangan Kabupaten Minahasa Selatan, dengan alamat Jl. Trans Sulawesi, Kelurahan Pondang, Kecamatan Amurang, Kabupaten Minahasa Selatan.

\subsection{Metode Pengumpulan Data \\ Jenis Data}

Adapun jenis data yang digunakan dalam penelitian ini adalah data kualitatif yaitu data yang dinyatakan bukan dalam bentuk angka melainkan dapat berupa kata, skema, atau gambar. Dalam penelitian kualitatif, pengumpulan data tidak di pandu oleh teori, tetapi dipandu oleh fakta-fakta yang ditemukan pada saat penelitian di lapangan. Oleh karena itu analisis data yang dilakukan bersifat induktif berdasarkan fakta-fakta yang ditemukan dan kemudian dapat dikontruksikan menjadi hipotesis atau teori (Sugiyono : 2016). 


\section{Sumber Data}

Sumber data adalah sesuatu yang dapat memberikan informasi mengenai data. Adapun data yang saya peroleh melalui:

a. Data primer yaitu penelitian data secara langsung dengan mengadakan penelitian terhadap objek yang diteliti untuk memperoleh data primer, dengan melakukan wawancara kepada pihak yang bersangkutan.

b. Data sekunder yaitu data yang diperoleh peneliti secara tidak langsung melalui media perantara (Melihat penelitian yang sudah pernah dilakukan sebelumnya), menggunakan metode tinjauan kepustakaan (library research) membaca buku-buku yang berkaitan dengan masalah yang ingin diteliti, dan dilihat dari mengakses website dan situs-situs yang berkaitan.

\section{Teknik Pengumpulan Data}

1. Wawancara

2. Dokumentasi

\subsection{Metode Analisis}

Metode analisis yang digunakan dalam penelitian ini adalah metode deskriptif adalah mengumpulkan, mengklasifikasikan, menganalisa, dan menginterprestasikan data-data yang diperoleh dari objek penelitian sehingga dapat memberikan gambaran yang jelas sesuai keadaan yang sebenarnya. Selain itu juga menggambarkan atau membandingkan serta menguraikan suatu data sehingga dapat ditarik suatu kesimpulan dari data tersebut guna melengkapi penelitian ini.

\section{HASIL ANALISIS DAN PEMBAHASAN}

\subsection{Hasil Penelitian}

Pajak yang dipotong oleh bendahara pada Badan Perencanaan Penelitian Dan Pembangunan Daerah Kabupaten Minahasa Selatan adalah Pajak Penghasilan Pasal 21 Atas Honorarium, Pajak Penghasilan Pasal 22 Atas Pembelian ATK, dan Pajak Pertambahan Nilai Atas Pembelian Barang.

Tabel 4.2 Pemotongan Pajak Penghasilan Pasal 21 Atas Honorarium Bulan Agustus

\begin{tabular}{|c|c|c|c|}
\hline Masa Pajak & Objek Pajak & $\begin{array}{c}\text { Dasar Pengenaan } \\
\text { Pajak }\end{array}$ & $\begin{array}{l}\text { PPh Pasal } 21 \text { Atas } \\
\text { Honorarium 5\% } \\
\text { (Gol III) \& } 15 \% \\
\text { (Gol IV) }\end{array}$ \\
\hline $\begin{array}{ll}15 & \text { Agustus } \\
2016 & \end{array}$ & $\begin{array}{l}\text { Pembayaran Belanja Honorarium Panitia Pelaksanaan } \\
\text { Kegiatan Tim Pelatihan BimbinganTeknis Penyusunan } \\
\text { Renja Kerja Satuan Kerja Perangkat Daerah Kab. Minsel } \\
\text { Tahun } 2016 \text { a. n. Drs. Danny H. Rindengan, M. Si }\end{array}$ & Rp. 5.500.000 & Rp. 825.000 \\
\hline $\begin{array}{l}15 \text { Agustus } \\
2016\end{array}$ & $\begin{array}{l}\text { Pembayaran Belanja Honorarium Panitia Pelaksanaan } \\
\text { Kegiatan Tim Pelatihan BimbinganTeknis Penyusunan } \\
\text { Renja Kerja Satuan Kerja Perangkat Daerah Kab. Minsel } \\
\text { Tahun } 2016 \text { a. n. DR. M. J. Maindoka, M.Si } \\
\end{array}$ & Rp. 5.000 .000 & Rp. 750.000 \\
\hline $\begin{array}{l}15 \\
2016\end{array}$ & $\begin{array}{l}\text { Pembayaran Belanja Honorarium Panitia Pelaksanaan } \\
\text { Kegiatan Tim Pelatihan BimbinganTeknis Penyusunan } \\
\text { Renja Kerja Satuan Kerja Perangkat Daerah Kab. Minsel } \\
\text { Tahun } 2016 \text { a. n. Albert Tumbel, STP }\end{array}$ & Rp. 4.500 .000 & Rp. 675.000 \\
\hline \multirow[t]{2}{*}{$\begin{array}{ll}15 & \text { Agustus } \\
2016 & \end{array}$} & $\begin{array}{l}\text { Pembayaran Belanja Honorarium Panitia Pelaksanaan } \\
\text { Kegiatan Tim Pelatihan BimbinganTeknis Penyusunan } \\
\text { Renja Kerja Satuan Kerja Perangkat Daerah Kab. Minsel } \\
\text { Tahun } 2016 \text { a. n. Drs. Julian L. Mangowal } \\
\end{array}$ & Rp. 4.000 .000 & Rp. 600.000 \\
\hline & $\begin{array}{l}\text { Pembayaran Belanja Honorarium Panitia Pelaksanaan } \\
\text { Kegiatan Tim Pelatihan BimbinganTeknis Penyusunan } \\
\text { Renja Kerja Satuan Kerja Perangkat Daerah Kab. Minsel } \\
\text { Tahun } 2016 \text { a. n. Denly C. V. Rompis, SST, MM } \\
\end{array}$ & Rp. 2.500 .000 & Rp. 125.000 \\
\hline
\end{tabular}




\begin{tabular}{|c|c|c|c|}
\hline Masa Pajak & Objek Pajak & $\begin{array}{c}\text { Dasar Pengenaan } \\
\text { Pajak }\end{array}$ & $\begin{array}{l}\text { PPh Pasal } 21 \text { Atas } \\
\text { Honorarium 5\% } \\
\text { (Gol III) \& } 15 \% \\
\text { (Gol IV) }\end{array}$ \\
\hline & $\begin{array}{l}\text { Pembayaran Belanja Honorarium Panitia } \text { Pelaksanaan } \\
\text { Kegiatan Tim Pelatihan BimbinganTeknis } \\
\text { Renja Kerja Satuan Kerja Perangkat Daerah } \\
\text { Tahun } 2016 \text { a. n. Jootje Tuerah, MM } \\
\end{array}$ & Rp. 1.500 .000 & Rp. 225.000 \\
\hline & $\begin{array}{l}\text { Pembayaran Belanja Honorarium Panitia Pelaksanaan } \\
\text { Kegiatan Tim Pelatihan BimbinganTeknis Penyusunan } \\
\text { Renja Kerja Satuan Kerja Perangkat Daerah Kab. Minsel } \\
\text { Tahun } 2016 \text { a. n. Drs. Efer F. R. Poluakan }\end{array}$ & Rp. 1.500 .000 & Rp. 225.000 \\
\hline & $\begin{array}{l}\text { Pembayaran Belanja Honorarium Panitia } \text { Pelaksanaan } \\
\text { Kegiatan Tim Pelatihan BimbinganTeknis Penyusunan } \\
\text { Renja Kerja Satuan Kerja Perangkat Daerah Kab. Minsel } \\
\text { Tahun } 2016 \text { a. n. Hendry Lumapow, SH } \\
\end{array}$ & Rp. 1.500 .000 & Rp. 225.000 \\
\hline & $\begin{array}{l}\text { Pembayaran Belanja Honorarium Panitia Pelaksanaan } \\
\text { Kegiatan Tim Pelatihan BimbinganTeknis } \text { Penyusunan } \\
\text { Renja Kerja Satuan Kerja Perangkat Daerah Kab. Minsel } \\
\text { Tahun } 2016 \text { a. n. Altin Sualang, SSTP }\end{array}$ & Rp. 1.500 .000 & Rp. 75.000 \\
\hline & $\begin{array}{l}\text { Pembayaran Belanja Honorarium Panitia Pelaksanaan } \\
\text { Kegiatan Tim Pelatihan BimbinganTeknis Penyusunan } \\
\text { Renja Kerja Satuan Kerja Perangkat Daerah Kab. Minsel } \\
\text { Tahun } 2016 \text { a. n. Danny P. Repi, S.Pi, MM } \\
\end{array}$ & Rp. 1.500 .000 & Rp. 75.000 \\
\hline & $\begin{array}{l}\text { Pembayaran Belanja Honorarium Panitia Pelaksanaan } \\
\text { Kegiatan Tim Pelatihan BimbinganTeknis Penyusunan } \\
\text { Renja Kerja Satuan Kerja Perangkat Daerah Kab. Minsel } \\
\text { Tahun } 2016 \text { a. n. Christofel R. K. Manopo, SE, MM } \\
\end{array}$ & Rp. 1.500 .000 & Rp. 75.000 \\
\hline & $\begin{array}{l}\text { Pembayaran Belanja Honorarium Panitia Pelaksanaan } \\
\text { Kegiatan Tim Pelatihan BimbinganTeknis Penyusunan } \\
\text { Renja Kerja Satuan Kerja Perangkat Daerah Kab. Minsel } \\
\text { Tahun } 2016 \text { a. n. Yoan M. Tirada, SE } \\
\end{array}$ & Rp. 1.500 .000 & Rp. 75.000 \\
\hline & $\begin{array}{l}\text { Pembayaran Belanja Honorarium Panitia Pelaksanaan } \\
\text { Kegiatan Tim Pelatihan BimbinganTeknis Penyusunan } \\
\text { Renja Kerja Satuan Kerja Perangkat Daerah Kab. Minsel } \\
\text { Tahun } 2016 \text { a. n. Ilona M. W. Lakoy, S.Pt, M.sc }\end{array}$ & Rp. 1.500 .000 & Rp. 75.000 \\
\hline & $\begin{array}{l}\text { Pembayaran Belanja Honorarium Panitia Pelaksanaan } \\
\text { Kegiatan Tim Pelatihan BimbinganTeknis Penyusunan } \\
\text { Renja Kerja Satuan Kerja Perangkat Daerah Kab. Minsel } \\
\text { Tahun } 2016 \text { a. n. Deysri R. Rumengan, SP } \\
\end{array}$ & Rp. 1.500 .000 & Rp. 75.000 \\
\hline
\end{tabular}

Sumber : Kantor Bapelitbang Kab. Minsel

Tabel 4.3 Pemotongan Pajak Penghasilan Pasal 22 Atas Pembelian Alat Tulis Kantor Bulan September

\begin{tabular}{|c|c|c|c|}
\hline Masa Pajak & Objek Pajak & $\begin{array}{ll}\text { Dasar } & \text { Pengenaan } \\
\text { Pajak } & \end{array}$ & $\begin{array}{ll}\text { Tarif } & \text { PPH } \\
\text { Pasal } 22 & \\
1,5 \% & \\
\end{array}$ \\
\hline $\begin{array}{ll}13 & \text { September } \\
2016 & \\
\end{array}$ & $\begin{array}{l}\text { Pembayaran Belanja ATK Penyusunan KUA-PPAS } \\
2017 \text { program perencanaan pembangunan daerah }\end{array}$ & Rp. 4.995 .000 & Rp. 68,114 \\
\hline $\begin{array}{ll}13 & \text { September } \\
2016 & \end{array}$ & $\begin{array}{l}\text { Pembayaran Belanja ATK Penyusunan RKPD tahun } \\
2017 \text { Program perencanaan pembangunan daerah }\end{array}$ & Rp. 5.000.000 & Rp. 68,182 \\
\hline $\begin{array}{ll}21 & \text { September } \\
2016 & \\
\end{array}$ & Pembayaran Alat Tulis Kantor Triwulan II Tahun 2016 & Rp. 10.247 .700 & Rp. 139,741 \\
\hline $\begin{array}{l}\text { 21 September } \\
2016\end{array}$ & $\begin{array}{l}\text { Pembayaran Belanja Pengadaan penyusunan RKPD } \\
2017 \text { program perencanaan pembangunan daerah }\end{array}$ & Rp. 4.983 .750 & Rp. 498.375 \\
\hline 21 September & $\begin{array}{c}\text { Pembayaran Belanja Penggadaan penyelenggaraan } \\
\text { forum SKPD }\end{array}$ & Rp. 2.726 .850 & Rp. 272.685 \\
\hline $\begin{array}{l}21 \text { September } \\
2016\end{array}$ & $\begin{array}{c}\text { Pembayaran Belanja Penggadaan Bimbingan Teknis } \\
\text { Penyusunan Rencana Kerja SKPD }\end{array}$ & Rp. 1.984 .100 & Rp. 198.410 \\
\hline
\end{tabular}


Tabel 4.4 Pemotongan Pajak Pertambahan Nilai Atas Pembelian Barang Bulan September

\begin{tabular}{|c|c|c|c|}
\hline Masa Pajak & Objek Pajak & $\begin{array}{c}\text { Dasar } \\
\text { Pengenaan } \\
\text { Pajak }\end{array}$ & $\begin{array}{c}\text { Tarif Pajak } \\
\text { Pertambahan } \\
\text { Nilai } 10 \%\end{array}$ \\
\hline $\begin{array}{l}13 \text { September } \\
2016\end{array}$ & $\begin{array}{l}\text { Pembayaran belanja ATK Koordinasi dan Evaluasi APBN } \\
\text { Program Pembangunan Data/Informasi }\end{array}$ & Rp. 1.294 .000 & Rp. 17,654 \\
\hline $\begin{array}{l}13 \text { September } \\
2016\end{array}$ & $\begin{array}{l}\text { Pembayaran Belanja ATK Penyusunan KUA-PPAS } 2017 \\
\text { program perencanaan pembangunan daerah }\end{array}$ & Rp. 4.995 .000 & Rp. 68,114 \\
\hline $\begin{array}{l}13 \text { September } \\
2016\end{array}$ & $\begin{array}{l}\text { Pembayaran Belanja ATK Penyusunan RKPD tahun } 2017 \\
\text { Program perencanaan pembangunan daerah }\end{array}$ & Rp. 5.000 .000 & Rp. 68,182 \\
\hline $\begin{array}{l}21 \text { September } \\
2016\end{array}$ & Pembayaran Alat Tulis Kantor Triwulan II Tahun 2016 & Rp. 10.247 .700 & Rp. 139,741 \\
\hline $\begin{array}{l}21 \text { September } \\
2016\end{array}$ & $\begin{array}{c}\text { Pembayaran Belanja Pengadaan penyusunan RKPD } 2017 \\
\text { program perencanaan pembangunan daerah }\end{array}$ & Rp. 4.983 .750 & Rp. 498.375 \\
\hline 21 September & $\begin{array}{l}\text { Pembayaran Belanja Penggadaan penyelenggaraan forum } \\
\text { SKPD }\end{array}$ & Rp. 2.726 .850 & Rp. 272.685 \\
\hline $\begin{array}{l}\text { 21 September } \\
2016\end{array}$ & $\begin{array}{c}\text { Pembayaran Belanja Penggadaan Bimbingan Teknis } \\
\text { Penyusunan Rencana Kerja SKPD }\end{array}$ & Rp. 1.984 .100 & Rp. 198.410 \\
\hline
\end{tabular}

Sumber : Kantor Bapelitbang Kab. Minsel

\section{Pelaporan PPh Pasal 21, Pasal 22, dan PPN Pada Bapelitbang}

Pelaporan adalah hal yang sangat penting, dimana wajib pajak harus melaporkan perhitungan dan pembayaran pajak pada Kantor Pelayanan Pajak (KPP) Pratama Amurang. Pelaporan Pajak mempunyai batas tanggal jatuh tempo, yang diatur dalam Pasal 9 UU No. 28 Tahun 2007 Ketentuan Umum Perpajakan. Pada setiap bulan bendaharawan akan memotong Pajak Penghasilan Pasal 21, Pasal 22, dan Pajak Pertambahan Nilai, dan melakukan penyetoran pajak yang akan dipotong menggunakan e-billing agar menjadi lebih mudah dan akurat, dengan menggunakan (SSP) PPh Pasal 21, Pasal 22, dan PPN ke kas Negara melalui Teller BNI Amurang dengan menggunakan SPT Masa PPh Pasal 21, Pasal 22, PPN ke Kantor Pelayanan Pajak (KPP) Pratama Amurang dengan cara mengisi SPT dilampirkan juga bukti pemotongan, cetak bukti penerimaan Negara dan SSP. Jika lembar tersebut dinyatakan lengkap maka pihak KPP Pratama Amurang memberikan bukti penerimaan surat.

\section{Tabel 4.5 Pelaporan PPh Pasal 21Bapelitbang Kab. Minsel}

\begin{tabular}{ll}
\hline Masa Pajak & Pelaporan SPT \\
\hline Juli 2016 & - \\
Agustus 2016 & $15 / 08 / 2016$ \\
September 2016 & $05 / 09 / 2016$ \\
Oktober 2016 & $06 / 10 / 2016$ \\
November 2016 & - \\
Desember 2016 & - \\
\hline Sumber : Kantor Bapelitbang Kab. Minsel
\end{tabular}

Tahel 4.6 Pelaporan PPh Pasal 22 Bapelithang Kah. Minsel

Masa Pajak Juli 2016

Agustus 2016

September 2016

Oktober 2016

November 2016

Desember 2016

Sumber : Kantor Bapelitbang Kab. Minsel

\section{Pelaporan SPT}

\section{$24 / 08 / 2016$}

$09 / 09 / 2016$

$19 / 10 / 2016$

$13 / 11 / 2016$ 
Tabel 4.7 Pelaporan PPN Bapelitbang Kab. Minsel

\begin{tabular}{ll}
\hline Masa Pajak & Pelaporan SPT \\
\hline Juli 2016 & - \\
Agustus 2016 & - \\
September 2016 & $20 / 09 / 2016$ \\
Oktober 2016 & $19 / 10 / 2016$ \\
November 2016 & - \\
Desember 2016 & - \\
\hline
\end{tabular}

Sumber : Kantor Bapelitbang Kab. Minsel

Tabel 4.8 Perbandingan antara Aturan Hukum dan Pelaksanaan Pemotongan dan Pelaporan Pajak Pada bapelitbang

\begin{tabular}{|c|c|c|c|}
\hline Deskripsi & Aturan Hukum & Pelaksanaan & Kesimpulan \\
\hline $\begin{array}{l}\text { Pemotongan } \\
\text { PPh Pasal } 21\end{array}$ & $\begin{array}{l}\text { Peraturan Direktur Jenderal Pajak Nomor: } \\
\text { PER16/PJ/2016 tentang pedoman teknis tata } \\
\text { cara pemotongan, penyetoran, dan pelaporan } \\
\text { pajak penghasilan pasal } 21 \text { dan/atau pajak } \\
\text { penghasilan pasal } 26 \text { sehubungan dengan } \\
\text { pekerjaan, jasa, dan kegiatan orang pribadi. } \\
\text { Perhitungan Pemotongan PPh Pasal } 21 \text { atas } \\
\text { Honorarium pegawai (penghasilan yang menjadi } \\
\text { beban APBN atau APBD) PNS golongan I \& II } \\
\text { tarif } 0 \% \text {, golongan III tarif 5\%, sedangkan } \\
\text { golongan IV tarif } 15 \% \text {. }\end{array}$ & $\begin{array}{l}\text { Pemotongan PPh Pasal } 21 \text { dilakukan atas } \\
\text { Honorarium, Pelaksanaan pemotongan PPh } \\
\text { Pasal } 21 \text { atas Honorarium pada Bapelitbang } \\
\text { dilukan pemotongan untuk pegawai yang } \\
\text { mengikuti kegiatan pelatihan yang } \\
\text { memiliki golongan III menggunakan tarif } \\
5 \% \text { dan untuk golongan IV menggunakan } \\
\text { tarif 15\%. Dan yang bertanggung jawab } \\
\text { untuk memotong PPh pasal } 21 \text { adalah staf } \\
\text { dari Ibu Yoan, kemudian Ibu Yoan } \\
\text { memverifikasi kembali pemotongan yang } \\
\text { dilakukan oleh staf tersebut apa sudah } \\
\text { sesuai dengan peraturan yang berlaku. } \\
\text { Dengan perhitungan: Dasar Pengenaan } \\
\text { Pajak X PPh Pasal } 21 \text { atas Honorarium ( } \\
\text { golongan III dengan tarif 5\% dan golongan } \\
\text { IV tarif 15\%) }\end{array}$ & Sudah Sesuai \\
\hline $\begin{array}{l}\text { Pelaporan PPh } \\
\text { Pasal } 21\end{array}$ & $\begin{array}{l}\text { Peraturan Direktur Jenderal Pajak Nomor: } \\
\text { PER16/PJ/2016 tentang pedoman teknis tata } \\
\text { cara pemotongan, penyetoran, dan pelaporan } \\
\text { pajak penghasilan pasal } 21 \text { dan/atau pajak } \\
\text { penghasilan pasal } 26 \text { sehubungan dengan } \\
\text { pekerjaan, jasa, dan kegiatan orang pribadi. } \\
\text { Berdasarkan Peraturan Direktur Jenderal Pajak } \\
\text { Nomor: PER16/PJ/2016 Tata Cara Pelaporan } \\
\text { PPh Pasal } 21 \\
\text { Saat Pelaporan = Paling lambat tanggal } 20 \\
\text { bulan. Formulir yang dilaporkan menggunakan } \\
\text { SPT Masa PPh Pasal 21, daftar Bukti } \\
\text { Pemotongan PPh Pasal 21, surat Setoran Pajak } \\
\text { (SSP) lembar ke-3 }\end{array}$ & $\begin{array}{l}\text { Pelaporan PPh Pasal } 21 \text { dilakukan oleh Ibu } \\
\text { Yoan dengan menggunakan e-filling. } \\
\text { Formulir yang dilaporkan menggunakan } \\
\text { SPT Masa PPh Pasal } 21 \text { 1721, daftar Bukti } \\
\text { Pemotongan PPh Pasal 21, surat Setoran } \\
\text { Pajak (SSP) lembar ke-3, melakukan } \\
\text { pelaporan di Kantor Pelayanan Pajak pada } \\
\text { tanggal } 15 \text { Agustus 2017, } 5 \text { September } \\
\text { 2017, } 6 \text { Oktober 2017. Dan tidak } \\
\text { melaporkan pajak secara manual. }\end{array}$ & Sudah Sesuai \\
\hline $\begin{array}{l}\text { Pemotongan } \\
\text { PPh Pasal } 22\end{array}$ & $\begin{array}{l}\text { Peraturan Menteri Keuangan Republik } \\
\text { Indonesia Nomor 34/PMK.010/2017 tentang } \\
\text { Pemungutan Pajak Penghasilan Pasal } 22 \\
\text { sehubungan dengan pembayaran atas } \\
\text { penyerahan barang dan kegiatan di bidang } \\
\text { Impor atau Kegiatan Usaha di bidang lain. } \\
\text { Perhitungan Pemotongan PPh Pasal } 22 \text { dengan } \\
\text { tatif } 1,5 \% \text {. }\end{array}$ & $\begin{array}{l}\text { Saat pemotongan PPh Pasal } 22 \text { adalah pada } \\
\text { setiap pelaksanaan } \\
\text { pembayaran atas penyerahan barang oleh } \\
\text { rekanan, yang dibiayai dari APBN/APBD. } \\
\text { Pemotongan PPh pasal } 22 \text { dilakukan oleh } \\
\text { staf Ibu Yoan, kemudian diverifikasi } \\
\text { kembali oleh Ibu Yoan apakah sudah sesuai } \\
\text { dengan tarif yang berlaku. } \\
\text { Pemotongan PPh Pasal } 22 \text { dikenakan atas } \\
\text { pembelian Alat Tulis Kantor, dengan } \\
\text { menngunakan tarif } 1,5 \% \text {. }\end{array}$ & Sudah Sesuai \\
\hline $\begin{array}{l}\text { Pelaporan PPh } \\
\text { Pasal } 22\end{array}$ & $\begin{array}{l}\text { Berdasarkan Peraturan Menteri Keuangan } \\
\text { Republik Indonesia Nomor 34/PMK.010/2017 } \\
\text { TATA CARA PELAPORAN } \\
\text { a) Pemungut PPh Pasal } 22 \text { wajib menyampaikan } \\
\text { SPT Masa PPh Pasal } 22 \text { Belanja Negara dan } \\
\text { disampaikan paling lama } 14 \text { (empat belas) hari } \\
\text { setelah bulan takwim berakhir. Apabila hari ke- } \\
14 \text { jatuh pada hari libur, maka pelaporan } \\
\text { dilakukan pada hari kerja berikutnya. } \\
\text { b) SPT Masa tersebut disampaikan ke KPP atau } \\
\text { KP2KP dimana Pemungut yang bersangkutan } \\
\text { terdaftar dengan dilampiri lembar ke-3 SSP } \\
\text { sebagai Bukti Pemungutan dan bukti setoran, }\end{array}$ & $\begin{array}{l}\text { Pelaporan PPh Pasal } 22 \text { dilakukan oleh Ibu } \\
\text { Yoan dilakukan pada saat menyetorkan PPh } \\
\text { pasal } 22 \text { pada tanggal } 24 \text { Agustus 2017, } 9 \\
\text { September 2017, } 19 \text { Oktober 2017, 13 } \\
\text { November 2017 di Kantor Pelayanan Pajak } \\
\text { melaporkan SPT melalui e-filling, dengan } \\
\text { menggunakan formulir SPT Masa PPh } \\
\text { Pasal 22, lembar ke-3. Tidak lagi } \\
\text { melaporkan SPT secara manual. }\end{array}$ & Tidak Sesuai \\
\hline
\end{tabular}




\begin{tabular}{|c|c|c|c|}
\hline Deskripsi & Aturan Hukum & Pelaksanaan & Kesimpulan \\
\hline & beserta Daftar SSP PPh Pasal 22. & & \\
\hline $\begin{array}{l}\text { Pemotongan } \\
\text { Pajak } \\
\text { Pertambahan } \\
\text { Nilai }\end{array}$ & $\begin{array}{l}\text { Berdasarkan Undang-Undang Nomor } 42 \text { Tahun } \\
2009 \text { tentang Perubahan Ketiga Atas Undang- } \\
\text { Undang Nomor } 8 \text { tahun } 1983 \text { tentang Pajak } \\
\text { Pertambahan Nilai barang dan jasa dan Pajak } \\
\text { penjualan atas barang mewah, tarif Pajak } \\
\text { Pertambahan Nilai adalah sebesar } 10 \% \text { atas } \\
\text { pembelian Barang Kena Pajak. }\end{array}$ & $\begin{array}{l}\text { Pemotongan Pajak Pertambahan Nilai } \\
\text { dikenakan atas pembelian barang dan jasa } \\
\text { untuk peralatan kantor Bapelitbang. } \\
\text { Perhitungan atau pemotngan PPN } \\
\text { dilakukan oleh staf Ibu Yoan, kemudia } \\
\text { diverifikasi kembali oleh Ibu Yoan untuk } \\
\text { melihat melihat apakah sudah sesuai } \\
\text { dengan tarif yang berlaku. Dan } \\
\text { Pemotongan PPN menggunakan tarif } 10 \% \text {. }\end{array}$ & Sudah Sesuai \\
\hline $\begin{array}{l}\text { Pelaporan } \\
\text { Pajak } \\
\text { Pertambahan } \\
\text { Nilai }\end{array}$ & $\begin{array}{l}\text { Berdasarkan Undang-Undang Nomor } 42 \text { Tahun } \\
2009 \text { pelaporan PPN dan PPnBM - } \\
\text { Bendaharawan batas waktu pelaporan PPN Tgl. } \\
14 \text { bulan berikut. }\end{array}$ & $\begin{array}{l}\text { Pelaporan Pajak Pertambahan Nilai } \\
\text { dilakukan oleh Ibu Yoan melalui e-filling } \\
\text { pada tanggal } 20 \text { September } 2017 \text { dan } 19 \\
\text { Oktober 2017. Formulir yang dilaporkan } \\
\text { yaitu SPT Masa PPN 1111. Tidak } \\
\text { melaporkan PPn secara manual. }\end{array}$ & Tidak Sesuai \\
\hline
\end{tabular}

\section{KESIMPULAN DAN SARAN}

\subsection{Kesimpulan}

\section{Kesimpulan}

Berdasarkan hasil penelitian dan pembahasan, maka dapat ditarik kesimpulan sebagai berikut:

1. Pemotongan dan Pelaporan PPh Pasal 21 Atas Honorarium telah dilakukan sesuai dengan peraturan perpajakan yang berlaku.

2. Pemotongan dan Pelaporan PPh Pasal 22 Atas Pembelian ATK telah sesuai dengan pemotongan (tarif 1,5\%) dan batas waktu pelaporan belum sesuai berdasarkan peraturan perpajakan.

3. Pemotongan PPN Atas Pembelian Barang telah dilakukan sesuai dengan peraturan perpajakan yang berlaku dan untuk pelaporan PPN belum sesuai berdasarkan peraturan perpajakan.

\subsection{Saran}

Berdasarkan kesimpulan, maka saran yang ingin disampaikan penulis adalah:

1. Bendahara Badan Perencanaan Penelitian dan Pembangunan Kabupaten Minahasa Selatan diharapkan terus mempertahankan tingkat ketelitian dan pengawasan dalam melakukan pemotongan pajak.

2. Badan Perencanaan Penelitian dan Pembangunan Kabupaten Minahasa Selatan sebaiknya melaporkan pajak sesuai dengan peraturan perpajakan, sehingga dikemudian hari tidak terjadi sanksi perpajakan.

\section{DAFTAR PUSTAKA}

Albertus Indratno, 2013. Prinsip-Prinsip Dasar Akuntansi. Penerbit Dunia Cerdas.

Clivan Thomas Sorongan, 2014. Perhitungan Dan Pelaporan Pajak Penghasilan

Pasal 22 Atas Pengadaan Barang Pada Kantor Pelayanan Perbendaharaan Negara Kota Bitung.

David Wasao, 2014. The Effect Of Online Tax System On Tax Compliance Among

Small Taxpayers In East Of Nairobi Tax District. 
Dina Pomeranz, 2014. No Taxation without Information Deterrence and SelfEnforcement in the Value Added Tax.

Harnanto, 2013. Perencanaan Pajak. Cetakan Pertama. BPFE. Yogyakarta.

Hezron Ioanes Budiarto, 2012. Evaluasi Mekanisme PPh Pasal 22 Bendaharawan Pemerintah Pada PPPTMGB "LEMIGAS.

Irsan Lubis, 2015. Mahir Akuntansi Pajak Terapan Berbasis Standar Akuntansi \& Ketentuan Pajak Terbaru. Penerbit Andi. Yogyakarta.

Kiki Ratnafuri, 2012. Malpraktek Pemotongan dan Pelaporan Pajak Oleh Bendahara Pemerintah.

Mardiasmo, 2016. Perpajakan (Rev). Penerbit Andi. Yogyakarta.

Mardiasmo, 2011. Perpajakan.Penerbit Andi. Yogyakarta.

Sugiono, 2016. Penelitian Kualitatif. Alfabeta Bandung.

Supriyanto, Eddy, 2011. Akuntansi Perpajakan. Edisi Pertama. Graha Ilmu. Yogyakarta.

Tmbooks, 2013. Perpajakan-Esensi dan Aplikasi. Penerbit Andi. Yogyakarta. 